\title{
Reduction of Native Diversity by Invasive Plants Depends on Habitat Conditions
}

\author{
Yvonne Künzi, Daniel Prati, Markus Fischer, Steffen Boch* \\ Institute of Plant Sciences and Botanical Garden, University of Bern, Bern, Switzerland \\ Email: ${ }^{*}$ steffen.boch@ips.unibe.ch
}

Received 14 September 2015; accepted 27 October 2015; published 30 October 2015

Copyright (C) 2015 by authors and Scientific Research Publishing Inc.

This work is licensed under the Creative Commons Attribution International License (CC BY). http://creativecommons.org/licenses/by/4.0/

(c) (i) Open Access

\begin{abstract}
Invasions by exotic plant species and their impacts on invaded communities are a highly topical field of research because it provides a basis for the management of neophyte populations. However, for many invasive neophyte species in Central Europe little is known about their impacts on invaded plant communities. Moreover, it has hardly been considered whether effects vary among habitat conditions. Here, we selected each ten sites with different habitat conditions invaded by Erigeron annuus, Fallopia japonica, Impatiens glandulifera and Solidago canadensis which were listed as invasive in Switzerland. At each site, we established four $4 \mathrm{~m} \times 1 \mathrm{~m}$ subplots covering a gradient from very low to very high cover of the particular neophyte species to investigate the effect of increasing neophyte cover on the species richness, Shannon diversity and evenness of the invaded plant communities. Moreover, we measured soil $\mathrm{pH}$ and characterized habitat conditions using Ellenberg indicator values to light and soil fertility. Whereas increasing cover of I. glandulifera had no effect on the diversity of invaded plant communities, an increasing cover of $E$. annuus negatively affected Shannon diversity. An increasing cover of $F$. japonica combined with a decreasing soil $\mathrm{pH}$ negatively affected the Shannon diversity of invaded plant communities. Similarly, an increasing cover of $\boldsymbol{S}$. canadensis in combination with decreasing soil fertility negatively affected the Shannon diversity and evenness of invaded communities. Our results indicate that significant effects of increasing neophyte cover are mostly coupled to particular habitat conditions and then rather suppress than eliminate native plant species in invaded communities. We therefore suggest including abiotic variables in further impact studies on biotic invasions. Furthermore, adapting measures to the respective environmental context can be a useful tool in priority setting for the management of invasive neophyte populations and the restoration of invaded habitats.
\end{abstract}

\section{Keywords}

Diversity Impact of Neophytes, Indicator Values, Plant Species Richness

\footnotetext{
${ }^{*}$ Corresponding author.
}

How to cite this paper: Künzi, Y., Prati, D., Fischer, M. and Boch, S. (2015) Reduction of Native Diversity by Invasive Plants Depends on Habitat Conditions. American Journal of Plant Sciences, 6, 2718-2733. 


\section{Introduction}

Global biodiversity is declining continuously [1] [2] with severe consequences for ecosystem functioning and human well-being [3] [4]. Introduced, alien species are generally considered among the most important drivers of biodiversity decline [5], although only few of the thousands of species that have been introduced to new ranges actually establish and become invasive [6] [7]. Thus, identifying those introduced species which really cause environmental problems or threaten native species is the major goal of invasion biology.

Introduced alien plant species that became invasive may exert a range of impacts, including changes in nutrient cycling [8] [9], fire regimes [10], habitat structure [11], biotic homogenizations [12] [13], and facilitation of invasions by other alien species [14]. Several studies aimed to find general effects of alien plants across species, habitats or spatial scales [15]-[18], which were however criticized because the impacts of plant invasions were not universal [19] and depended on both, the introduced species and the resident community which was invaded [20] [21]. Moreover, although several introduced alien plant species have been found to decrease the diversity of resident plant species [20] [22]-[24], especially in Central Europe their ecological impacts remain poorly studied. Cases of negative effects of alien plants are often anecdotal or based on subjective impressions and have rarely been verified in quantitative studies.

Vegetation data are scarce available before and after an invasion [25]. Thus, most impact studies used the “space for time substitution approach", comparing invaded with uninvaded sites [20] [22]-[24] [26] [27]. However, this approach bears uncertainties about the comparability of invaded and uninvaded sites because these sites can differ markedly in other environmental conditions than just the presence of neophytes [15] [20]. Reduced diversity in invaded plots may have been the cause for successful establishment of alien species rather than their effect. Furthermore, the comparison of invaded and uninvaded plots represents the "worst-case scenarios” [19], but does not provide any information on the impact along an abundance gradient of alien plants [28]. An alternative would be the "gradient approach", where plots that vary in the dominance of an alien target species are compared within a site, thereby assessing different stages of invasion. As this approach has only rarely been tested (but see [24] [29]), it is largely unknown how varying abundances of alien species affect the diversity of invaded communities [28]. For management and restoration considerations, it would further be valuable to know whether the resident vegetation can benefit from a partial neophyte population reduction in cases where complete eradication is not feasible or affordable.

Introduced, alien species are generally considered to be superior competitors, because they grow fast and competition for light is one of the most commonly used explanations for negative effects on invaded plant communities (e.g. [26] [30]). Moreover, belowground competition [21], allelopathic suppression of native species ([31]-[33]; evolution of increased competitive ability hypothesis: [34]) and mycorrhyzation depletion of native species (e.g. [35]; novel weapons hypothesis: [36]) have been suggested to negatively affect the resident vegetation. However, allelopathy has not explained the invasion success of neophyte species in general [37] [38].

Interestingly, whether the context dependency such as varying habitat conditions influences the effects of neophyte species on the diversity of resident communities has hardly been tested, although it has been proposed (e.g. [21] [28] [39]), and the impact of a neophyte species seems to differ among invaded habitat types [22]. Given the vast variety of species and systems and the very little fraction of which have been studied, it is likely that many impacts have remained undiscovered [14]. Therefore, further case studies on neophyte species from different regions seem to be essential for improving the knowledge and practice required for risk assessment and handling of specific neophyte populations in a given area.

Outside the context of biotic invasions, environmental variables are recognized as important determinants of vegetation characteristics. Light availability, soil $\mathrm{pH}$, and soil nutrient content are three main factors that affect the species richness of plant communities [40] [41]. Moreover, interactions of effects often have a more critical ecological impact than the corresponding main effects on their own [42]. Studies addressing the effect of neophyte species on the diversity of invaded plant communities, however, often ignore the influence of environmental variables and their interaction with the effect of an invasion on vegetation characteristics.

Here, we investigated whether the increasing cover of four invasive alien species decreased the diversity of invaded communities in the region of Bern, Switzerland, using four of the putatively worst invasive species in Switzerland (Erigeron annuus, Fallopia japonica, Impatiens glandulifera and Solidago canadensis). All four species were considered as neophytes as they were introduced after 1492. Previous studies reported negative effects of F. japonica and S. canadensis on resident plant diversity [20] [22]-[24], whereas results were ambiguous 
for I. glandulifera (e.g. [27] [43]) or to our knowledge absent for E. annuus. We also measured several environmental variables to test whether the effect of increasing neophyte cover depended on the environmental condition, a question rarely addressed in previous impact studies.

Our main questions were:

1) What is the impact of an increasing neophyte cover on the diversity of plant communities?

2) Do the strength and direction of the impact on the diversity of invaded plant communities depend on environmental conditions?

\section{Methods}

\subsection{Species}

We selected four invasive neophytes which are all listed in the black list of invasive plants of Switzerland (see https://www.infoflora.ch/de/flora/neophyten/listen-und-infoblätter.html): Erigeron annuus (annual fleabane; Asteraceae), Fallopia japonica (syn. Reynoutria japonica; Japanese knotweed; Polygonaceae), Impatiens glandulifera (Himalayan balsam; Balsaminaceae) and Solidago canadensis (Canadian goldenrod; Asteraceae). Furthermore, F. japonica, I. glandulifera, and S. canadensis are listed in the Ordinance on the Handling of Organisms in the Environment of the Federal Law in Switzerland (Freisetzungsverordnung, FrSV; SR 814.911), which regulates the handling with hazardous organisms, their metabolic products and wastes to protect humans, animals and the environment. Fallopia japonica is native in Japan, China and Korea. It is a rhizomatous perennial plant with can reach a height of $3 \mathrm{~m}$. Mainly in riparian ecosystems, along roadsides and waste places it forms large and dense colonies. Impatiens glandulifera is native to the Himalayas. It is a large annual plant which can grow up to $2.5 \mathrm{~m}$. It has explosive capsules which can eject the seeds over several meters. It mostly grows in riparian areas, especially on river edges and in wetlands. Solidago canadensis is native to North America. It is a perennial herb and can grow up to $2.5 \mathrm{~m}$. It produces huge numbers of seeds which can be dispersed over long distances by wind. Alternatively, the plant can reproduce vegetatively through rhizomes. It grows in various ruderal and riparian habitats. Erigeron annuus is native to North America. It is a biennial plant which grows up to $1.5 \mathrm{~m}$. It produces huge numbers of seeds which can be dispersed over long distances by wind. The typical ruderal plant invades various habitats.

\subsection{Site Selection}

Our study was conducted in the Swiss lowland in a radius of approximately $25 \mathrm{~km}$ around Bern, Switzerland (see Table S1 for site coordinates). For each target species, we selected ten invaded sites in different habitats, based on occurrence data provided by Info Flora (www.infoflora.ch), the national data and information center for the Swiss flora, as well as from own observations. We considered a site to be suitable if it was well accessible, not mown when the vegetation was assessed and harbored one of the target species at a sufficient density. Furthermore, the environmental conditions had to be homogeneous meaning that the whole site could be assigned to one habitat type.

\subsection{Vegetation Sampling}

At each site, we established up to four $4 \mathrm{~m} \times 1 \mathrm{~m}$ plots covering a gradient from very low to very high cover of the particular target species and marked the plots permanently. In five sites we sampled only two and in two sites only three plots, because the population of the target species was too small or parts of the site had been mown. Thus, the total number of plots was 148 (40 with I. glandulifera and each 36 with E. annuus, F. japonica and S. canadensis).

Between June and August 2013 we recorded all vascular plant species in each plot and estimated their percentage cover, and grouped them into three vegetation layers: 1) a herb-layer comprising all non-woody plants, but including tree and shrub seedlings, 2) a shrub-layer comprising woody plants up to $5 \mathrm{~m}$ height and 3) a tree-layer comprising all woody plants taller than $5 \mathrm{~m}$. Nomenclature of vascular plants follows Lauber et al. ([44]).

From this data we calculated the plant species richness $(S)$, Shannon diversity $\left(H^{\prime}\right)$ as $H^{\prime}=-\sum p_{i} \times \ln p_{i}$, and evenness $\left(J^{\prime}\right)$ as $J^{\prime}=H^{\prime} / \ln S$, where $p_{i}$ is the proportion of species $i$ per plot. We calculated these separately for all species and all native herbaceous species (total number of species minus the number of neophyte 
and woody species), but never included the target species of the corresponding plot. For the assessment of further abiotic conditions, we further calculated the cover weighted mean Ellenberg indicator values [45] for soil fertility and light. Ellenberg indicator values describe the realized niche position along several environmental gradients on an ordinal scale from 1 to 9 and are widely used to describe ecological conditions based on vegetation records [46]. All recorded species were included in the calculation of the soil fertility indicator value, whereas for the light indicator value, species of the tree layer were excluded, because we focused on the understory vegetation.

\subsection{Soil Data}

In each plot, we prepared a composite soil sample by mixing four randomly placed soil cores of $10 \mathrm{~cm}$ after removing the litter layer. These soil samples were subsequently air dried in open plastic bags and sieved to $<2 \mathrm{~mm}$. To obtain the $\mathrm{pH}$, we mixed $5 \mathrm{~g}$ of soil of each soil sample with $12.5 \mathrm{ml}$ distilled water, shook it for two hours, and measured the $\mathrm{pH}$ with a Mettler Toledo Seven Easy ${ }^{\mathrm{TM}} \mathrm{pH}$ Meter S20, which had previously been calibrated with a two point calibration at $\mathrm{pH} 4$ and $\mathrm{pH} 7$.

\subsection{Statistical Analyses}

All analyses were performed using R, Version 3.0.2 [47]. To test the effects of the cover of each target species on the diversity of native species and native herbaceous species (species richness, Shannon diversity, and evenness), we used mixed-effect models by following the ten step protocol in Zuur et al. ([48]), using the package nlme [49]. The full model contained the cover of target neophyte, soil $\mathrm{pH}$, soil fertility indicator value, light indicator value, as well as the two-way interactions between cover of target neophyte and the other factors as fixed effects and site as random effect. We simplified the models by omitting non-significant effects and selected the model with the lowest AIC (Akaike Information Criterion). We always kept the cover of target neophyte in the model and did not exclude main effects when their interaction with cover of target neophyte remained in the model. In cases where the cover of the target neophyte as well as its interaction with another factor were significant in the final model we tentatively dropped the interaction term. If the cover of target neophyte effect remained significant in the resulting model, it was a generally applicable one. If the significance of the cover effect was lost, this indicated that it was coupled to the corresponding interaction and thus restricted to sites within a certain range of the respective interacting factor. To display the partial effect of neophyte cover on the diversity measurement of each model, we created partial regression plots [50]. Significant interactions were illustrated with 3D plots based on predicted values from the respective selected models.

\section{Results}

\subsection{Characteristics of Invaded Plant Communities}

Average species richness and plant community composition differed among the four target neophyte species (Table S2 and Table S3). Plots invaded by E. annuus harbored the highest number of species (mean $=25.69$, standard error \pm 0.68 ), followed by plots of S. canadensis (22.86 \pm 0.86 ). Plots of F. japonica and I. glandulifera harbored a mean number of $13.89( \pm 1.31)$ and $11.77( \pm 0.81)$ native species, respectively. The number of native herbaceous species followed the same order. The cover of the target neophyte ranged from $1 \%$ to $85 \%$ in plots of E. annuus (mean $=30.42 \pm 3.94$ ) and S. canadensis (36.83 \pm 4.41 ), from $1 \%$ to $95 \%$ in I. glandulifera (41.64 \pm 4.54 ) and from $1 \%$ to $100 \%$ in plots of $F$. japonica (51.78 \pm 5.78 ). For ranges and mean values of all considered variables see Table S3.

\subsection{Effect of Erigeron annuus Cover on Plant Diversity}

Increasing cover of $E$. annuus did not affect the species richness and the evenness, but decreased the Shannon diversity of invaded communities (slope $-0.004, p=0.02$, Figure 1(a), Figure 1(c), Table S4). However, with increasing soil fertility, an increasing cover of $E$. annuus negatively affected species richness of invaded communities as indicated by the significant cover-by-soil fertility interaction ( $p=0.03$; Figure 2$)$. In addition, the Shannon diversity of invaded communities decreased by the factor 0.004 with an increase in $1 \%$ cover of $E$. annuus (slope $-0.004, p=0.02$; Figure 1(b); Table S4). 


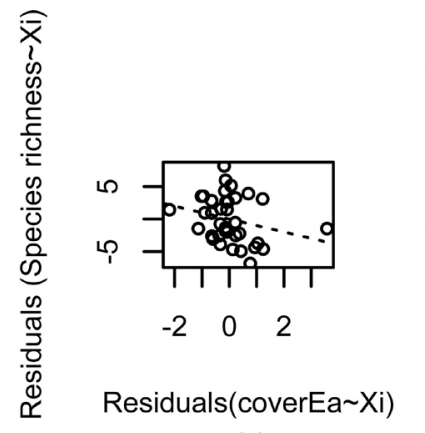

(a)

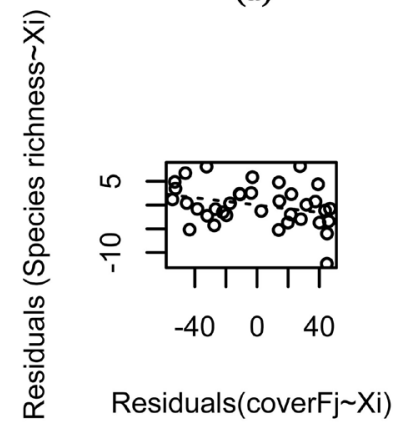

(d)

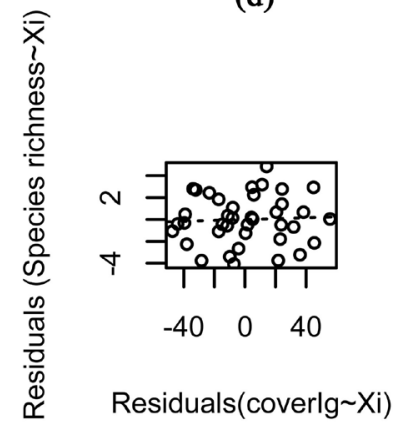

(g)

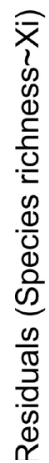

Residuals(coverSc Xi)

(k)
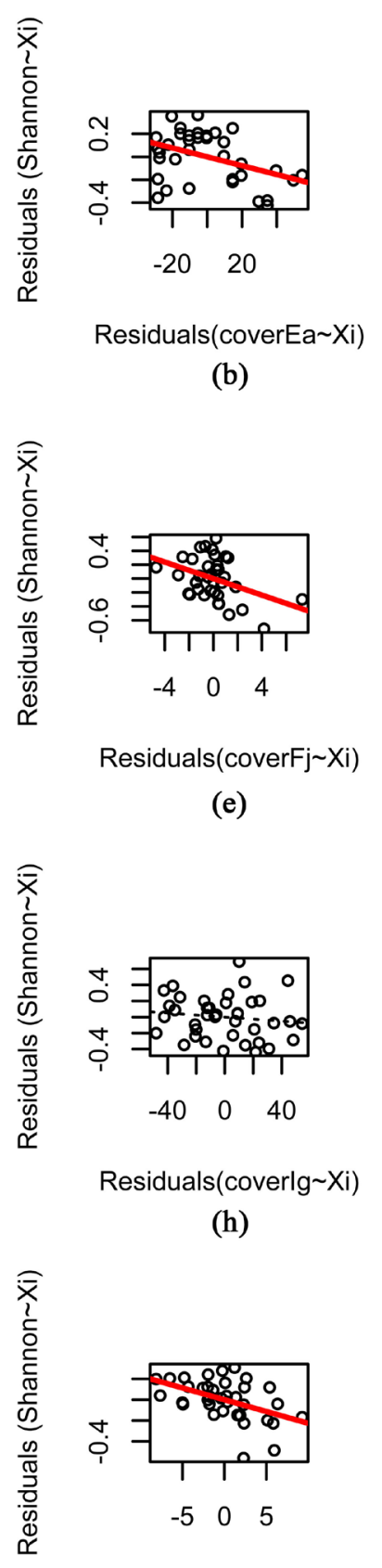

(b)

(e)

(h)

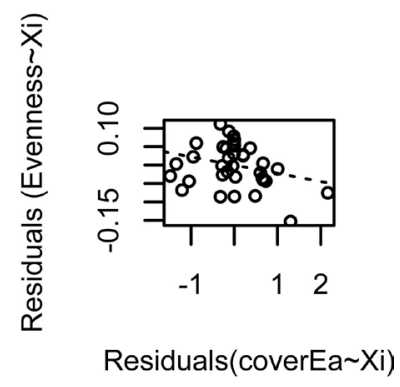

(c)

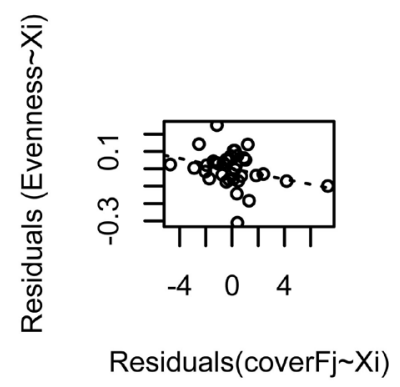

(f)

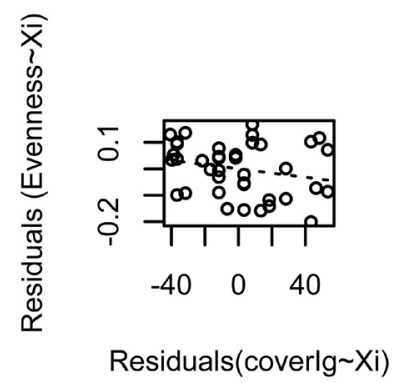

(i)

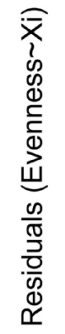

Residuals(coverSc $\sim \mathrm{Xi}$ )

(1)

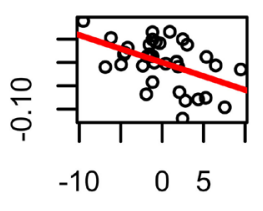

Residuals(coverSc $\sim$ Xi)

(m)

Figure 1. Partial regression plots on the effects the target neophyte cover on species richness, Shannon diversity and eveness: E. annuus ((a)-(c)), F. japonica ((d)-(f)), I. glandulifera ((g)-(i)), and S. canadensis ((k)-(m)). Note the different axes scales. Red lines indicate significant effects $(p<0.05)$.

\subsection{Effect of Fallopia japonica Cover on Plant Diversity}

Species richness and evenness of invaded communities were not affected by an increasing cover of $F$. japonica (Figure 1(d), Figure 1(f)). However, with decreasing soil $\mathrm{pH}$ an increasing cover of $F$. japonica negatively affected the Shannon diversity of invaded communities, as indicated by the significant cover-by-soil $\mathrm{pH}$ interaction ( $p<0.01$; Figure 3; Table S5). 


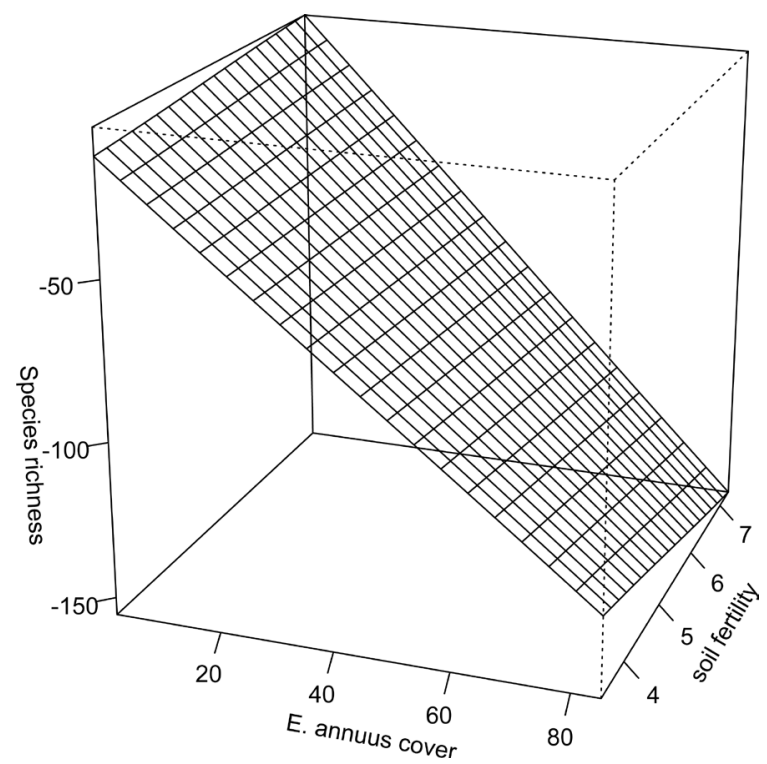

Figure 2. Erigeron annuus cover-by-soil fertility effect on the species richness of invaded communities. Please note that the values on the y-axes are predicted values obtained from the respective final model. The negative values result from the model's imperfect explanation of reality.

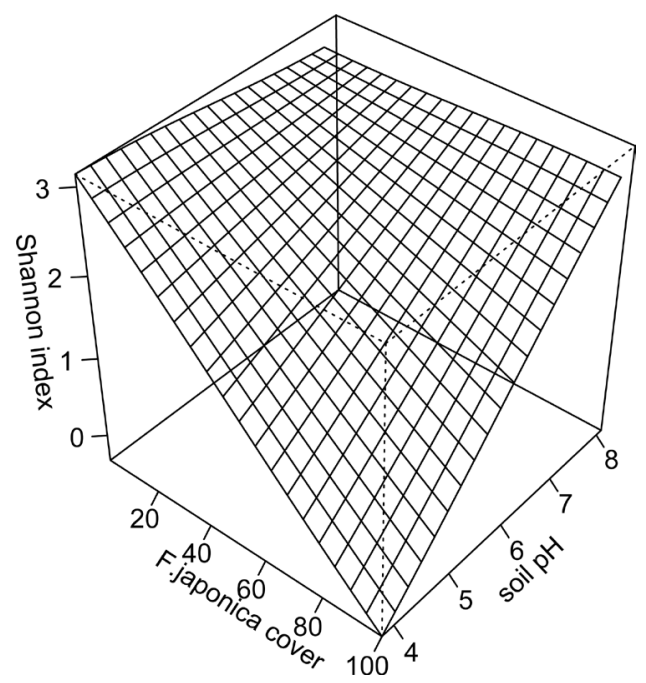

Figure 3. Fallopia japonica cover-by-soil pH effect on the Shannon diversity of invaded communities. The values on the $\mathrm{y}$-axes are predicted values obtained from the respective final model.

\subsection{Effect of Impatiens glandulifera Cover on Plant Diversity}

We found no effect of I. glandulifera cover on the species richness, Shannon diversity and evenness of invaded communities (Figures 1(g)-(i)). Moreover, no interactions remained in any of the selected models (Table S6).

\subsection{Effect of Solidago canadensis Cover on Plant Diversity}

We found no significant effect of an increasing S. canadensis cover on the species richness of the invaded communities (Figure 1(k)). Interestingly, with a decreasing soil $\mathrm{pH}$ an increasing S. canadensis cover positively affected the richness of native herbaceous species, as indicated by the significant cover-by-soil $\mathrm{pH}$ interaction ( $p$ $=0.04$; Figure 4). However, with decreasing soil fertility an increasing cover of $S$. canadensis negatively affected Shannon diversity and evenness of invaded communities, as indicated by the significant cover-by-soil fertility interactions (both $p<0.01$; Figure 5 and Figure 6; Table S7). 


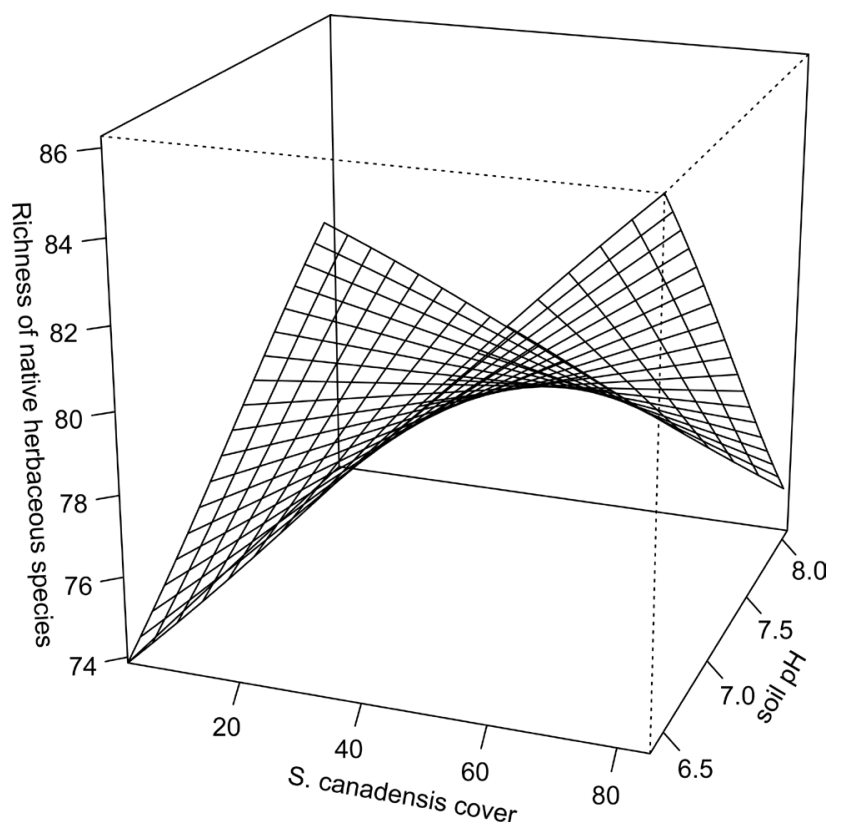

Figure 4. Solidago canadensis cover-by-soil pH effect on the richness of native herbaceous species of invaded communities. The values on the y-axes are predicted values obtained from the respective final model.

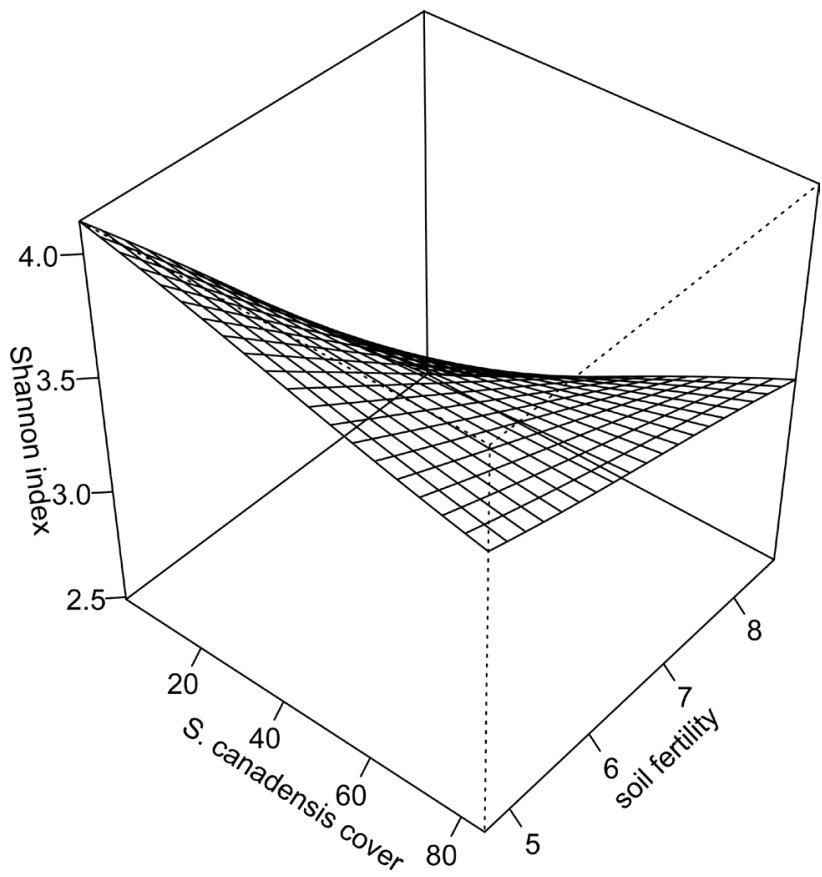

Figure 5. Solidago canadensis cover-by-soil fertility effect on the Shannon diversity of invaded communities. The values on the $y$-axes are predicted values obtained from the respective final models.

\section{Discussion}

The aim of this study was to investigate the impact of four neophyte species on the diversity of invaded communities by comparing plots with different cover of the target neophytes. There is a wealth of impact studies, but many of them solely investigated the effect of neophyte species on the species richness of a plant community (e.g. [15] [23] [24]), although changes in evenness or dominance patterns have been shown to affect properties of plant communities, such as productivity or invasion resistance, independently of its species richness ([51] 


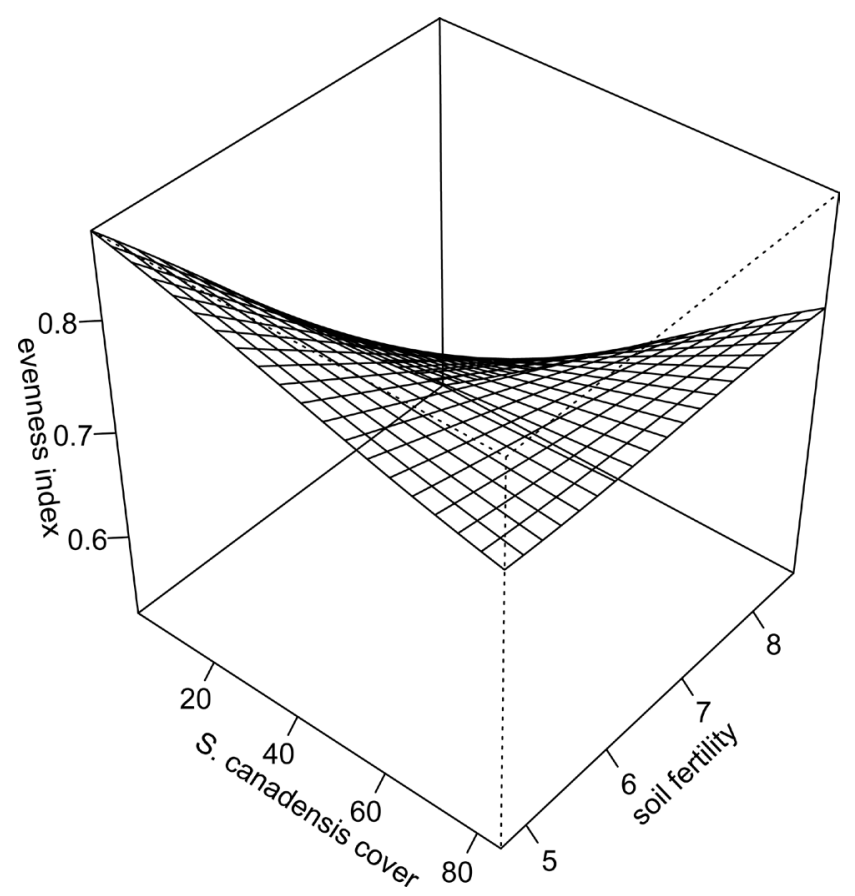

Figure 6. Solidago canadensis cover-by-soil fertility effect on the evenness of invaded communities. The values on the y-axes are predicted values obtained from the respective final models.

[52]). In contrast to previous studies, we found no effect of the four investigated neophytes on the species richness of invaded communities. This is rather surprising, given the competitive ability and various impacts that have been reported for these species (e.g. [13] [20] [22]-[24] [35] [53]-[57]). Independent of the aboveground neophyte cover it might be possible that the species richness in our invaded sites was already reduced due to neophyte species driven allelopathic suppression of native species ([31] [33]; evolution of increased competitive ability hypothesis: [34]) and mycorrhyzation depletion of native species (e.g. [35]; novel weapons hypothesis: [36]). However, no general patterns have been found and the topic is contrarily discussed (e.g. [37] [58] [59]).

In our study, the effect of increasing neophyte cover markedly differed among the diversity measurements, and species richness was the least affected one which corresponds to Hejda et al. [20]. More importantly, our findings highlight the importance of considering environmental variables in impact studies because significant effects of increasing neophyte cover on diversity measurements were mainly associated with abiotic site conditions (significant cover-by-abiotic factor interactions). The only direct main effect we found was the decreased Shannon diversity with increasing cover of $E$. annuus. Although this species has become abundant in many parts of Europe during the last century [60], and negative effects on the diversity of the invaded communities have been assumed [55], its impact has never been quantified.

Most previous studies did not test for differences among environmental variables in the effect of neophyte species on the diversity of invaded plant communities, which might have affected their results. Pyšek et al. [42] pointed out that decisive ecological impacts often appear in interactions with other effects and that invasion impacts are context dependent. Moreover, using the example of $F$. japonica, Bimova et al. [22] found that its impact on resident vegetation differed among habitat types and Parepa et al. [59] pointed out site-specific factors like soil conditions to affect $F$. japonica invasions. Thus, it is likely that the diversity of plant communities is at least co-determined by variables other than the presence and cover of a neophyte species.

Interestingly, we found that an increasing $S$. canadensis cover in combination with decreasing soil $\mathrm{pH}$ positively affected species richness of native herbaceous species (significant cover-by-soil pH interaction). A possible explanation for this finding could be a partial replacement of native dominant species such as the frequently occurring Urtica dioica (see Table S2) by S. canadensis. This is in line with Chen et al. ([13]) who showed that $S$. canadensis can locally replace dominant species in invaded habitats. Moreover, $U$. dioica is considered to pose even worse threat to vegetation types than alien invaders [61]. By partially replacing $U$. dioica in habitats, where this species would otherwise be very abundant and strongly dominate the vegetation (i.e. plots with com- 
parably low $\mathrm{pH}$ ), S. canadensis could thus positively affect the richness of native herbaceous species (the cover of $U$. dioica was negatively correlated with the number of native herbaceous species $(p<0.001)$ and the cover of S. canadensis $(p<0.02)$ ).

Another important finding is that increasing cover of $S$. canadensis did not generally negatively affected the diversity of invaded communities, but only in combination with decreasing soil fertility indicator values (as indicated by the significant cover-by-soil fertility interactions). However, the negative effect of $S$. canadensis on the diversity in low productive habitats can be problematic as these habitats often harbor a high species richness and many rare species (e.g. dry grasslands: [62] [63]), whereas in habitats without limitation by nutrients, plant communities are likely dominated by tall nitrophilous species which do not differ in the impact on native plant communities from dominant neophytes (e.g. [27]). High soil-nutrient levels reduce the plant diversity via increased above-ground biomass, height and competition for light [64]-[66]. Thus, productive habitats are mainly dominated by competitive species and the species richness tends to be low. When these competitive species are then replaced by a neophyte it is likely that the diversity is not affected by the invasion. These results indicate that the habitat type can play a role for the strength of the invasion impact and that an invasion can represent a "passenger" of conditions that lead to lower species richness [30], rather than the cause of reduced diversity itself.

In contrast to Hulme and Bremner ([43]) who detected a reduction in species richness and diversity by more than $25 \%$ when I. glandulifera was present, but in line with Hejda et al. ([20]) who studied effects of 13 neophyte species on the species richness of native plant communities, we found no effect of I. glandulifera cover on any of the considered diversity measurements. Reasons for this might be the heterogeneity of I. glandulifera stands, allowing other species to co-occur, and the likely very small belowground competition because I. glandulifera is an annual plant without rhizomes [20]. Moreover, the main growth period of I. glandulifera is rather late, suggesting relevant light competition to occur only in midsummer, which levels off the consequences for the earlier understory vegetation. Indeed, the impact of this species on resident vegetation seems to be far less severe than feared due to its impressive growth and habit in midsummer [67].

\section{Conclusion}

In our study, an increasing neophyte cover did not generally negatively affect the diversity of invaded plant communities and significant effects of increasing neophyte cover were mainly associated with abiotic site conditions. These interaction-coupled effects provide evidence that it is essential to include habitat variables when studying the effect of neophytes on the diversity of invaded plant communities. We therefore suggest including abiotic variables and a range of habitats in further impact studies on biotic invasions. From a more practical point of view, considering these varying impacts among different habitats can be used as a tool for priority setting in neophyte management programmes and the restoration of invaded habitats. In conclusion, resources and efforts of management programmes could be used more efficiently when focussing on species with severe impacts and on more sensitive habitats in which invasions tend to have a high impact.

\section{Acknowledgements}

We thank Armin Komposch, Judith Hinderling and Marlise Zimmermann for assistance and practical support in the lab, as well as Michele Naldoni and Info Flora for information on neophyte populations.

\section{References}

[1] Barnosky, A.D., Matzke, N., Tomiya, S., Wogan, G.O.U., Swartz, B., et al. (2011) Has the Earth’s Sixth Mass Extinction Already Arrived? Nature, 471, 51-57. http://dx.doi.org/10.1038/nature09678

[2] Pimm, S.L., Jenkins, C.N., Abell, R., Brooks, T.M., Gittleman, J.L., et al. (2014) The Biodiversity of Species and Their Rates of Extinction, Distribution, and Protection. Science, 344. http://dx.doi.org/10.1126/science.1246752

[3] Isbell, F., Calcagno, V., Hector, A., Connolly, J., Harpole, W.S., et al. (2011) High Plant Diversity Is Needed to Maintain Ecosystem Services. Nature, 477, 199-202. http://dx.doi.org/10.1038/nature10282

[4] Cardinale, B.J., Duffy, J.E., Gonzalez, A., Hooper, D.U., Perrings, C., et al. (2012) Biodiversity Loss and Its Impact on Humanity. Nature, 486, 59-67. http://dx.doi.org/10.1038/nature11148

[5] Gurevitch, J. and Padilla, D.K. (2004) Are Invasive Species a Major Cause of Extinctions? Trends in Ecology and 
Evolution, 19, 470-474. http://dx.doi.org/10.1016/j.tree.2004.07.005

[6] Williamson, M. and Fitter, A. (1996) The Varying Success of Invaders. Ecology, 77, 1661-1666. http://dx.doi.org/10.2307/2265769

[7] van Kleunen, M., Dawson, W., Essl, F., Pergl, J., Winter, M., et al. (2015) Global Exchange and Accumulation of Non-Native Plants. Nature, 525, 100-103. http://dx.doi.org/10.1038/nature14910

[8] Asner, G.P. and Vitousek, P.M. (2005) Remote Analysis of Biological Invasion and Biogeochemical Change. Proceedings of the National Academy of Sciences of the United States of America, 102, 4383-4386. http://dx.doi.org/10.1073/pnas.0500823102

[9] Thorpe, A.S., Archer, V. and DeLuca, T.H. (2006) The Invasive Forb, Centaurea maculosa, Increases Phosphorus Availability in Montana Grasslands. Applied Soil Ecology, 32, 118-122. http://dx.doi.org/10.1016/j.apsoil.2005.02.018

[10] Rossiter, N.A., Setterfield, S.A., Douglas, M.M. and Hutley, L.B. (2003) Testing the Grass-Fire Cycle: Alien Grass Invasion in the Tropical Savannas of Northern Australia. Diversity and Distributions, 9, 169-176. http://dx.doi.org/10.1046/j.1472-4642.2003.00020.x

[11] Gan, X.J., Choi, C.Y., Wang, Y., Ma, Z.J., Chen, J.K. and Li, B. (2010) Alteration of Habitat Structure and Food Resources by Invasive Smooth Cordgrass Affects Habitat Use by Wintering Saltmarsh Birds at Chongming Dongtan, East China. Auk, 127, 317-327. http://dx.doi.org/10.1525/auk.2009.09147

[12] Schwartz, M.W., Thorne, J.H. and Viers, J.H. (2006) Biotic Homogenization of the California Flora in Urban and Urbanizing Regions. Biological Conservation, 127, 282-291. http://dx.doi.org/10.1016/j.biocon.2005.05.017

[13] Chen, G.Q., Zhang, C.B., Ma, L., Qiang, S., Silander, J.A. and Li, L.Q. (2013) Biotic Homogenization Caused by the Invasion of Solidago canadensis in China. Journal of Integrative Agriculture, 12, 835-845. http://dx.doi.org/10.1016/S2095-3119(13)60302-0

[14] Simberloff, D. (2011) How Common Are Invasion-Induced Ecosystem Impacts? Biological Invasions, 13, $1255-1268$. http://dx.doi.org/10.1007/s10530-011-9956-3

[15] Maskell, L.C., Firbank, L.G., Thompson, K., Bullock, J.M. and Smart, S.M. (2006) Interactions between Non-Native Plant Species and the Floristic Composition of Common Habitats. Journal of Ecology, 94, 1052-1060. http://dx.doi.org/10.1111/j.1365-2745.2006.01172.x

[16] Chrobock, T., Kempel, A., Fischer, M. and van Kleunen, M. (2011) Introduction Bias: Cultivated Alien Plant Species Germinate Faster and More Abundantly than Native Species in Switzerland. Basic and Applied Ecology, 12, $244-250$. http://dx.doi.org/10.1016/j.baae.2011.03.001

[17] Powell, K.I., Chase, J.M. and Knight, T.M. (2011) A Synthesis of Plant Invasion Effects on Biodiversity Across Spatial Scales. American Journal of Botany, 98, 539-548. http://dx.doi.org/10.3732/ajb.1000402

[18] Kempel, A., Chrobock, T., Fischer, M., Rohr, R.P. and van Kleunen, M. (2013) Determinants of Plant Establishment Success in a Multispecies Introduction Experiment with Native and Alien Species. Proceedings of the National Academy of Sciences of the United States of America, 110, 12727-12732. http://dx.doi.org/10.1073/pnas.1300481110

[19] Stohlgren, T.J. and Rejmanek, M. (2014) No Universal Scale-Dependent Impacts of Invasive Species on Native Plant Species Richness. Biology Letters, 10, 5. http://dx.doi.org/10.1098/rsbl.2013.0939

[20] Hejda, M., Pysek, P. and Jarosik, V. (2009) Impact of Invasive Plants on the Species Richness, Diversity and Composition of Invaded Communities. Journal of Ecology, 97, 393-403. http://dx.doi.org/10.1111/j.1365-2745.2009.01480.x

[21] Hejda, M. (2013) Do Species of Invaded Communities Differ in Their Vulnerability to Being Eliminated by the Dominant Alien Plants? Biological Invasions, 15, 1989-1999. http://dx.doi.org/10.1007/s10530-013-0426-y

[22] Bimova, K., Mandak, B. and Kasparova, I. (2004) How Does Reynoutria Invasion Fit the Various Theories of Invasibility? Journal of Vegetation Science, 15, 495-504.

[23] de Groot, M., Kleijn, D. and Jogan, N. (2007) Species Groups Occupying Different Trophic Levels Respond Differently to the Invasion of Semi-Natural Vegetation by Solidago canadensis. Biological Conservation, 136, 612-617. http://dx.doi.org/10.1016/j.biocon.2007.01.005

[24] Gerber, E., Krebs, C., Murrell, C., Moretti, M., Rocklin, R. and Schaffner, U. (2008) Exotic Invasive Knotweeds (Fallopia spp.) Negatively Affect Native Plant and Invertebrate Assemblages in European Riparian Habitats. Biological Conservation, 141, 646-654. http://dx.doi.org/10.1016/j.biocon.2007.12.009

[25] Myers, J.H. and Bazely, D. (2003) Ecology and Control of Introduced Plants. Volume 62, Cambridge University Press, Cambridge. http://dx.doi.org/10.1017/CBO9780511606564

[26] Levine, J.M., Vila, M., D’Antonio, C.M., Dukes, J.S., Grigulis, K. and Lavorel, S. (2003) Mechanisms Underlying the Impacts of Exotic Plant Invasions. Proceedings of the Royal Society B-Biological Sciences, 270, 775-781. http://dx.doi.org/10.1098/rspb.2003.2327 
[27] Hejda, M. and Pysek, P. (2006) What Is the Impact of Impatiens glandulifera on Species Diversity of Invaded Riparian Vegetation? Biological Conservation, 132, 143-152. http://dx.doi.org/10.1016/j.biocon.2006.03.025

[28] Vila, M., Espinar, J.L., Hejda, M., Hulme, P.E., Jarosik, V., et al. (2011) Ecological Impacts of Invasive Alien Plants: A Meta-Analysis of Their Effects on Species, Communities and Ecosystems. Ecology Letters, 14, 702-708. http://dx.doi.org/10.1111/j.1461-0248.2011.01628.x

[29] Dostal, P., Mullerova, J., Pysek, P., Pergl, J. and Klinerova, T. (2013) The Impact of an Invasive Plant Changes over Time. Ecology Letters, 16, 1277-1284. http://dx.doi.org/10.1111/ele.12166

[30] MacDougall, A.S. and Turkington, R. (2005) Are Invasive Species the Drivers or Passengers of Change in Degraded Ecosystems? Ecology, 86, 42-55. http://dx.doi.org/10.1890/04-0669

[31] Oh, H., Lee, S., Lee, H.S., Lee, D.H., Lee, S.Y., et al. (2002) Germination Inhibitory Constituents from Erigeron annuus. Phytochemistry, 61, 175-179. http://dx.doi.org/10.1016/S0031-9422(02)00236-4

[32] Abhilasha, D., Quintana, N., Vivanco, J. and Joshi, J. (2008) Do Allelopathic Compounds in Invasive Solidago canadensiss L. Restrain the Native European Flora? Journal of Ecology, 96, 993-1001. http://dx.doi.org/10.1111/j.1365-2745.2008.01413.x

[33] Murrell, C., Gerber, E., Krebs, C., Parepa, M., Schaffner, U. and Bossdorf, O. (2011) Invasive Knotweed Affects Native Plants through Allelopathy. American Journal of Botany, 98, 38-43. http://dx.doi.org/10.3732/ajb.1000135

[34] Blossey, B. and Nötzold, R. (1995) Evolution of Increased Competitive Ability in Invasive Nonindigenous Plants: A Hypothesis. Journal of Ecology, 83, 887-889. http://dx.doi.org/10.2307/2261425

[35] Tanner, R.A. and Gange, A.C. (2013) The Impact of Two Non-Native Plant Species on Native Flora Performance: Potential Implications for Habitat Restoration. Plant Ecology, 214, 423-432. http://dx.doi.org/10.1007/s11258-013-0179-9

[36] Callaway, R.M. and Aschehout, E.T. (2000) Invasive Plants versus Their New and Old Neighbors: A Mechanism for Exotic Invasion. Science, 290, 521-523. http://dx.doi.org/10.1126/science.290.5491.521

[37] Del Fabbro, C. (2013) Allelopathy, Soil Biota and Plant Invasions. PhD Dissertation, University of Bern, Bern.

[38] Del Fabbro, C., Güsewell, S. and Prati, D. (2014) Allelopathic Effects of Three Plant Invaders on Germination of Native Species: A Field Study. Biological Invasions, 16, 1035-1042. http://dx.doi.org/10.1007/s10530-013-0555-3

[39] Wardle, D.A., Bardgett, R.D., Callaway, R.M. and Van der Putten, W.H. (2011) Terrestrial Ecosystem Responses to Species Gains and Losses. Science, 332, 1273-1277. http://dx.doi.org/10.1126/science.1197479

[40] Gough, L., Shaver, G.R., Carroll, J., Royer, D.L. and Laundre, J.A. (2000) Vascular Plant Species Richness in Alaskan Arctic Tundra: The Importance of Soil pH. Journal of Ecology, 88, 54-66. http://dx.doi.org/10.1046/j.1365-2745.2000.00426.x

[41] Hofmeister, J., Hosek, J., Modry, M. and Rolecek, J. (2009) The Influence of Light and Nutrient Availability on Herb Layer Species Richness in Oak-Dominated Forests in Central Bohemia. Plant Ecology, 205, 57-75. http://dx.doi.org/10.1007/s11258-009-9598-z

[42] Pysek, P., Jarosik, V., Hulme, P.E., Pergl, J., Hejda, M., et al. (2012) A Global Assessment of Invasive Plant Impacts on Resident Species, Communities and Ecosystems: The Interaction of Impact Measures, Invading Species' Traits and Environment. Global Change Biology, 18, 1725-1737. http://dx.doi.org/10.1111/j.1365-2486.2011.02636.x

[43] Hulme, P.E. and Bremner, E.T. (2006) Assessing the Impact of Impatiens glandulifera on Riparian Habitats: Partitioning Diversity Components Following Species Removal. Journal of Applied Ecology, 43, 43-50. http://dx.doi.org/10.1111/j.1365-2664.2005.01102.x

[44] Lauber, K., Wagner, G. and Gygax, A. (2012) Flora Helvetica. 5th Edition, Haupt Verlag, Bern.

[45] Ellenberg, H., Weber, H.E., Düll, R., Wirth, V. and Werner, W. (2001) Zeigerwerte von Pflanzen in Mitteleuropa. Scripta Geobotanica, 18, 1-262.

[46] Diekmann, M. (2003) Species Indicator Values as an Important Tool in Applied Plant Ecology-A Review. Basic and Applied Ecology, 4, 493-506. http://dx.doi.org/10.1078/1439-1791-00185

[47] R Development Core Team (2013) R: A Language and Environment for Statistical Computing. R Foundation for Statistical Computing, Vienna.http://www.R-project.org/

[48] Zuur, A., Ieno, E.N., Walker, N., Saveliev, A.A. and Smith, G.M. (2009) Mixed Effects Models and Extensions in Ecology with R. Springer, New York. http://dx.doi.org/10.1007/978-0-387-87458-6

[49] Pinheiro, J., Bates, D., DebRoy, S., Sarkar, D. and R Core Team (2014) Nlme: Linear and Nonlinear Mixed Effects Models. R Package Version 3, 1-117.

[50] Moya-Laraño, J. and Corcobado, G. (2008) Plotting Partial Correlation and Regression in Ecological Studies. Web Ecology, 8, 35-46. http://dx.doi.org/10.5194/we-8-35-2008 
[51] Wilsey, B.J. and Potvin, C. (2000) Biodiversity and Ecosystem Functioning: Importance of Species Evenness in an Old Field. Ecology, 81, 887-892. http://dx.doi.org/10.1890/0012-9658(2000)081[0887:BAEFIO]2.0.CO;2

[52] Smith, M.D., Wilcox, J.C., Kelly, T. and Knapp, A.K. (2004) Dominance Not Richness Determines Invasibility of Tallgrass Prairie. Oikos, 106, 253-262. http://dx.doi.org/10.1111/j.0030-1299.2004.13057.x

[53] Lowe, S., Browne, M., Boudjelas, S. and De Poorter, M. (2000) 100 of the World's Worst Invasive Alien Species. A Selection from the Global Invasive Species Database. The Invasive Species Specialist Group (ISSG), 12 p.

[54] Weber, E. (2003) Invasive Plant Species of the World: A Reference Guide to Environmental Weeds. CABI Publishing, Wallingford.

[55] Weber, E., Köhler, B., Gelpke, G., Perrenoud, A. and Gigon, A. (2005) Schlüssel zur Einteilung von Neophyten in der Schweiz in die Schwarze Liste oder die Watch-Liste. Botanica Helvetica, 115, 169-194. http://dx.doi.org/10.1007/s00035-005-0115-2

[56] Aguilera, A.G., Alpert, P., Dukes, J.S. and Harrington, R. (2010) Impacts of the Invasive Plant Fallopia japonica (Houtt.) on Plant Communities and Ecosystem Processes. Biological Invasions, 12, 1243-1252. http://dx.doi.org/10.1007/s10530-009-9543-z

[57] Stoll, P., Gatzsch, K., Rusterholz, H.P. and Baur, B. (2012) Response of Plant and Gastropod Species to Knotweed Invasion. Basic and Applied Ecology, 13, 232-240. http://dx.doi.org/10.1016/j.baae.2012.03.004

[58] Dostal, P. (2011) Plant Competitive Interactions and Invasiveness: Searching for the Effects of Phylogenetic Relatedness and Origin on Competition Intensity. American Naturalist, 177, 655-667. http://dx.doi.org/10.1086/659060

[59] Parepa, M., Fischer, M., Krebs, C. and Bossdorf, O. (2014) Hybridization Increases Invasive Knotweed Success. Evolutionary Applications, 7, 413-420. http://dx.doi.org/10.1111/eva.12139

[60] Edwards, P.J., Frey, D., Bailer, H. and Baltisberger, M. (2006) Genetic Variation in Native and Invasive Populations of Erigeron annuus as Assessed by RAPD Markers. International Journal of Plant Sciences, 167, 93-101. http://dx.doi.org/10.1086/498729

[61] Pearman, D.A. (2004) Invading Aliens-On Invading Natives. BSBI News, 96, 41-42.

[62] Dengler, J. and Boch, S. (2008) Sampling-Design Effects on Properties of Species-Area Relationships-A Case Study from Estonian Dry Grassland Communities. Folia Geobotanica, 43, 289-304. http://dx.doi.org/10.1007/s12224-008-9018-5

[63] Wilson, J.B., Peet, R.K., Dengler, J. and Pärtel, M. (2012) Plant Species Richness: The World Records. Journal of Vegetation Science, 23, 796-802. http://dx.doi.org/10.1111/j.1654-1103.2012.01400.x

[64] Hautier, Y., Niklaus, P.A. and Hector, A. (2009) Competition for Light Causes Plant Biodiversity Loss after Eutrophication. Science, 324, 636-638. http://dx.doi.org/10.1126/science.1169640

[65] Socher, S.A., Prati, D., Boch, S., Müller, J., Klaus, V.H., et al. (2012) Direct and Productivity-Mediated Indirect Effects of Fertilization, Mowing and Grazing on Grassland Species Richness. Journal of Ecology, 100, 1391-1399. http://dx.doi.org/10.1111/j.1365-2745.2012.02020.x

[66] Allan, E., Bossdorf, O., Dormann, C.F., Prati, D., Gossner, M.M., et al. (2014) Interannual Variation in Land-Use Intensity Enhances Grassland Multidiversity. Proceedings of the National Academy of Sciences of the United States of America, 111, 308-313. http://dx.doi.org/10.1073/pnas.1312213111

[67] Kowarik, I. (2003) Biologische Invasionen: Neophyten und Neozoen in Mitteleuropa. Ulmer, Stuttgart. 


\section{Supplementary}

Table S1. List of study sites by neophyte species with coordinates (Swiss grid).

\begin{tabular}{|c|c|}
\hline Site ID & Coordinates (Swiss grid) \\
\hline \multicolumn{2}{|c|}{ Erigeron annuus } \\
\hline EA 1 & $605126 / 201065$ \\
\hline EA 2 & $602456 / 203073$ \\
\hline EA 3 & $602380 / 203120$ \\
\hline EA 4 & $601370 / 203479$ \\
\hline EA 5 & 601569/199912 \\
\hline EA 6 & $601731 / 207250$ \\
\hline EA 7 & $601602 / 200063$ \\
\hline EA 8 & $599420 / 202897$ \\
\hline EA 9 & $594308 / 212890$ \\
\hline EA 10 & $580335 / 212313$ \\
\hline \multicolumn{2}{|c|}{ Fallopia japonica } \\
\hline FJ 1 & $601703 / 203523$ \\
\hline FJ 2 & $598587 / 200615$ \\
\hline FJ 3 & $598790 / 201930$ \\
\hline FJ 4 & $595858 / 201652$ \\
\hline FJ 5 & $600305 / 208372$ \\
\hline FJ 6 & $601120 / 203580$ \\
\hline FJ 7 & $588318 / 211436$ \\
\hline FJ 8 & $598733 / 202112$ \\
\hline FJ 9 & 602199/205691 \\
\hline FJ 10 & $599024 / 212498$ \\
\hline \multicolumn{2}{|c|}{ Impatiens glandulifera } \\
\hline IG 1 & $605881 / 200581$ \\
\hline IG 2 & $606083 / 200594$ \\
\hline IG 3 & $607340 / 218842$ \\
\hline IG 4 & $588196 / 211641$ \\
\hline IG 5 & $585116 / 196664$ \\
\hline IG 6 & $585062 / 196600$ \\
\hline IG 7 & $585081 / 196741$ \\
\hline IG 8 & $585840 / 202033$ \\
\hline IG 9 & $595912 / 200609$ \\
\hline IG 10 & $596531 / 200795$ \\
\hline \multicolumn{2}{|c|}{ Solidago canadensis } \\
\hline SC 1 & $601395 / 203077$ \\
\hline SC 2 & $601351 / 203596$ \\
\hline SC 3 & $598289 / 201082$ \\
\hline SC 4 & $601065 / 209880$ \\
\hline SC 5 & 601982/206581 \\
\hline SC 6 & $600219 / 208419$ \\
\hline SC 7 & $601398 / 208281$ \\
\hline SC 8 & $600829 / 209680$ \\
\hline SC 9 & $600700 / 209835$ \\
\hline SC 10 & $600234 / 206540$ \\
\hline
\end{tabular}




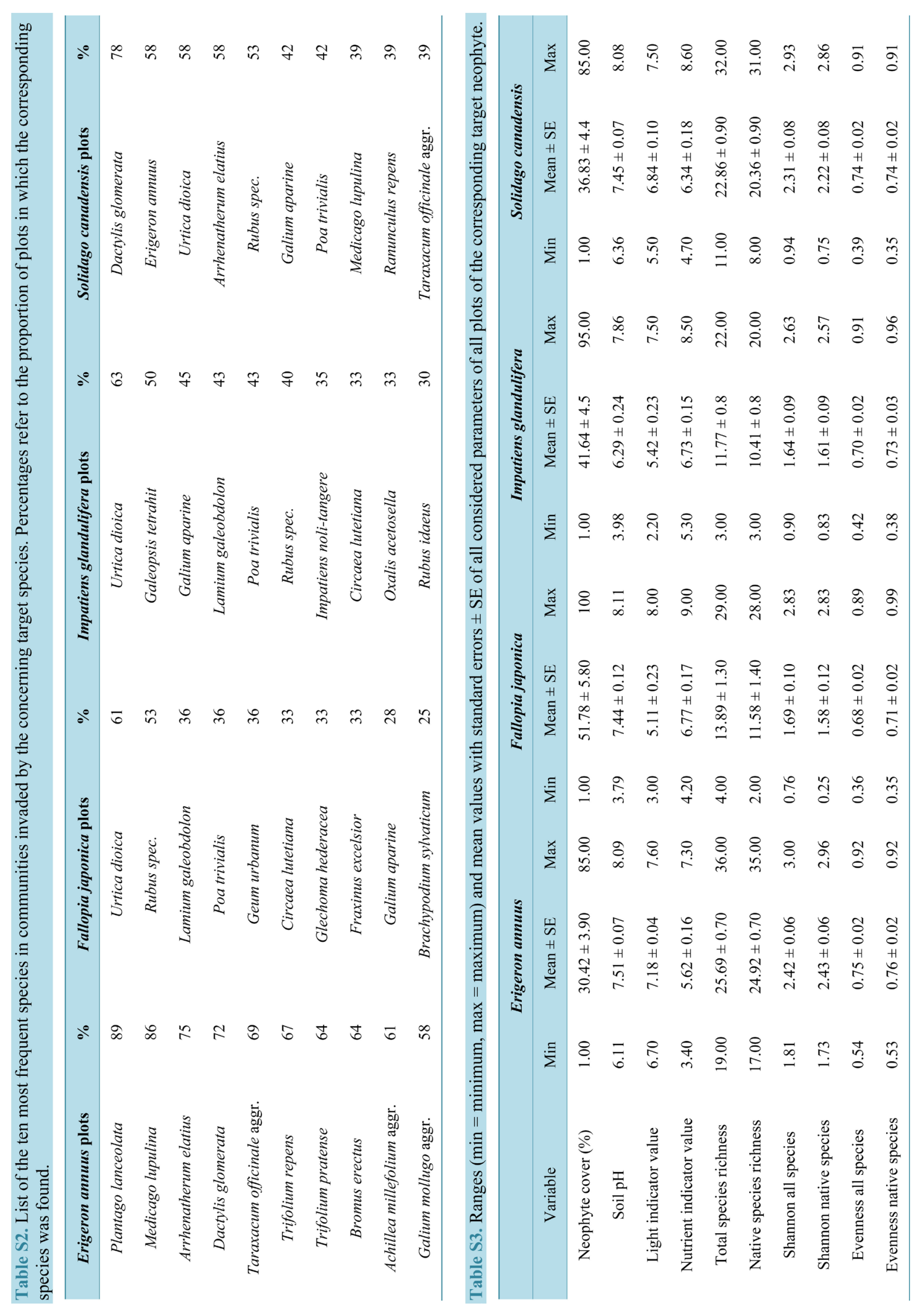


Table S4. Final models for E. annuus plots. Significant differences are indicated by bold values.

\begin{tabular}{|c|c|c|c|c|c|c|c|c|c|c|c|c|}
\hline \multirow{3}{*}{ Erigeron annuus } & \multicolumn{4}{|c|}{ Species richness } & \multicolumn{4}{|c|}{ Shannon diversity } & \multicolumn{4}{|c|}{ Evenness } \\
\hline & \multicolumn{2}{|c|}{ All species } & \multicolumn{2}{|c|}{$\begin{array}{l}\text { Herbaceous } \\
\text { species }\end{array}$} & \multicolumn{2}{|c|}{ All species } & \multicolumn{2}{|c|}{$\begin{array}{l}\text { Herbaceous } \\
\text { species }\end{array}$} & \multicolumn{2}{|c|}{ All species } & \multicolumn{2}{|c|}{$\begin{array}{l}\text { Herbaceous } \\
\text { species }\end{array}$} \\
\hline & Slope & $p$ & Slope & $p$ & Slope & $p$ & Slope & $p$ & Slope & $p$ & Slope & $p$ \\
\hline Neophyte cover (C) & -0.994 & 0.161 & -0.959 & 0.180 & -0.0044 & 0.023 & -0.0004 & 0.847 & -0.0259 & 0.121 & 0.0001 & 0.899 \\
\hline Soil $\mathrm{pH}(\mathrm{pH})$ & -2.168 & 0.392 & -1.951 & 0.445 & - & - & - & - & - & - & - & - \\
\hline Light indicator value (L) & 6.981 & 0.027 & 6.530 & 0.039 & -0.452 & 0.048 & -0.406 & 0.090 & -0.237 & 0.007 & -0.143 & $\mathbf{0 . 0 4 0}$ \\
\hline $\begin{array}{l}\text { Nitrogen indicator } \\
\text { value }(\mathrm{N})\end{array}$ & 2.571 & 0.045 & 1.916 & 0.133 & - & - & - & - & - & - & - & - \\
\hline $\mathrm{C} \times \mathrm{pH}$ & 0.215 & 0.068 & 0.200 & 0.091 & - & - & - & - & - & - & - & - \\
\hline $\mathrm{C} \times \mathrm{L}$ & - & - & - & - & - & - & - & - & 0.0034 & 0.137 & - & - \\
\hline $\mathrm{C} \times \mathrm{N}$ & -0.111 & 0.025 & -0.098 & 0.047 & - & - & - & - & - & - & - & - \\
\hline Random structure & \multicolumn{2}{|c|}{ gls } & \multicolumn{2}{|c|}{ gls } & \multicolumn{2}{|c|}{ Random intercept } & \multicolumn{2}{|c|}{ Random intercept } & \multicolumn{2}{|c|}{ Random intercept } & \multicolumn{2}{|c|}{ Random intercept } \\
\hline
\end{tabular}

Table S5. Final models for F. japonica plots. Significant differences are indicated by bold values.

\begin{tabular}{|c|c|c|c|c|c|c|c|c|c|c|c|c|}
\hline \multirow{3}{*}{ Fallopia japonica } & \multicolumn{4}{|c|}{ Species richness } & \multicolumn{4}{|c|}{ Shannon diversity } & \multicolumn{4}{|c|}{ Evenness } \\
\hline & \multicolumn{2}{|c|}{ All species } & \multicolumn{2}{|c|}{$\begin{array}{l}\text { Herbaceous } \\
\text { species }\end{array}$} & \multicolumn{2}{|c|}{ All species } & \multicolumn{2}{|c|}{$\begin{array}{l}\text { Herbaceous } \\
\text { species }\end{array}$} & \multicolumn{2}{|c|}{ All species } & \multicolumn{2}{|c|}{$\begin{array}{l}\text { Herbaceous } \\
\text { species }\end{array}$} \\
\hline & Slope & $p$ & Slope & $p$ & Slope & $p$ & Slope & $p$ & Slope & $p$ & Slope & $p$ \\
\hline Neophyte cover (C) & -0.044 & 0.091 & -0.028 & 0.249 & -0.072 & 0.023 & -0.011 & 0.182 & -0.015 & 0.093 & 0.000 & 0.993 \\
\hline Soil pH (pH) & - & - & - & - & -0.105 & 0.486 & 0.268 & 0.047 & -0.043 & 0.347 & 0.062 & 0.073 \\
\hline $\begin{array}{l}\text { Light indicator value } \\
\text { (L) }\end{array}$ & 1.755 & 0.057 & 2.528 & 0.007 & 0.124 & 0.069 & 0.108 & 0.313 & 0.026 & 0.058 & 0.035 & 0.051 \\
\hline $\begin{array}{l}\text { Nitrogen indicator } \\
\text { value }(\mathrm{N})\end{array}$ & -2.580 & 0.034 & -2.744 & 0.021 & -0.248 & 0.008 & -0.323 & 0.004 & -0.034 & 0.059 & - & - \\
\hline $\mathrm{C} \times \mathrm{pH}$ & - & - & - & - & 0.009 & 0.028 & - & - & 0.002 & 0.097 & - & - \\
\hline $\mathrm{C} \times \mathrm{L}$ & - & - & - & - & - & - & 0.002 & 0.200 & - & - & - & - \\
\hline $\mathrm{C} \times \mathrm{N}$ & - & - & - & - & - & - & - & - & - & - & - & - \\
\hline Random structure & \multicolumn{2}{|c|}{ Random intercept } & \multicolumn{2}{|c|}{ Random intercept } & \multicolumn{2}{|c|}{ Random intercept } & \multicolumn{2}{|c|}{ Random intercept } & \multicolumn{2}{|c|}{ gls } & \multicolumn{2}{|c|}{ gls } \\
\hline
\end{tabular}

Table S6. Final models for I. glandulifera plots. Significant differences are indicated by bold values.

\begin{tabular}{|c|c|c|c|c|c|c|c|c|c|c|c|c|}
\hline \multirow{3}{*}{ Impatiens glandulifera } & \multicolumn{4}{|c|}{ Species richness } & \multicolumn{4}{|c|}{ Shannon diversity } & \multicolumn{4}{|c|}{ Evenness } \\
\hline & \multicolumn{2}{|c|}{ All species } & \multicolumn{2}{|c|}{$\begin{array}{l}\text { Herbaceous } \\
\text { species }\end{array}$} & \multicolumn{2}{|c|}{ All species } & \multicolumn{2}{|c|}{$\begin{array}{l}\text { Herbaceous } \\
\text { species }\end{array}$} & \multicolumn{2}{|c|}{ All species } & \multicolumn{2}{|c|}{$\begin{array}{l}\text { Herbaceous } \\
\text { species }\end{array}$} \\
\hline & Slope & $p$ & Slope & $p$ & Slope & $p$ & Slope & $p$ & Slope & $p$ & Slope & $p$ \\
\hline Neophyte cover (C) & 0.005 & 0.790 & 0.006 & 0.687 & -0.001 & 0.470 & -0.0005 & 0.834 & -0.0009 & 0.175 & -0.0004 & 0.643 \\
\hline Soil pH (pH) & 1.631 & 0.045 & 1.457 & 0.047 & - & - & - & - & - & - & -0.0360 & 0.139 \\
\hline $\begin{array}{l}\text { Light indicator value } \\
\text { (L) }\end{array}$ & -1.570 & 0.028 & -1.815 & 0.008 & - & - & - & - & - & - & 0.0606 & 0.017 \\
\hline $\begin{array}{l}\text { Nitrogen indicator } \\
\text { value }(\mathrm{N})\end{array}$ & -1.614 & 0.079 & - & - & -0.166 & 0.094 & -0.216 & 0.050 & - & - & - & - \\
\hline $\mathrm{C} \times \mathrm{pH}$ & - & - & - & - & - & - & - & - & - & - & - & - \\
\hline $\mathrm{C} \times \mathrm{L}$ & - & - & - & - & - & - & - & - & - & - & - & - \\
\hline $\mathrm{C} \times \mathrm{N}$ & - & - & - & - & - & - & - & - & - & - & - & - \\
\hline Random structure & \multicolumn{2}{|c|}{ Random intercept } & \multicolumn{2}{|c|}{ Random intercept } & \multicolumn{2}{|c|}{ Random intercept } & \multicolumn{2}{|c|}{ Random intercept } & \multicolumn{2}{|c|}{ Random intercept } & \multicolumn{2}{|c|}{ gls } \\
\hline
\end{tabular}


Table S7. Final models for S. canadensis plots. Significant differences are indicated by bold values.

\begin{tabular}{|c|c|c|c|c|c|c|c|c|c|c|c|c|}
\hline \multirow{3}{*}{ Solidago canadensis } & \multicolumn{4}{|c|}{ Species richness } & \multicolumn{4}{|c|}{ Shannon diversity } & \multicolumn{4}{|c|}{ Evenness } \\
\hline & \multicolumn{2}{|c|}{ All species } & \multicolumn{2}{|c|}{ Herbaceous species } & \multicolumn{2}{|c|}{ All species } & \multicolumn{2}{|c|}{ Herbaceous species } & \multicolumn{2}{|c|}{ All species } & \multicolumn{2}{|c|}{ Herbaceous species } \\
\hline & Slope & $p$ & Slope & $p$ & Slope & $p$ & Slope & $p$ & Slope & $p$ & Slope & $p$ \\
\hline Neophyte cover (C) & -0.023 & 0.330 & 1.049 & 0.040 & -0.024 & 0.012 & -0.028 & 0.011 & -0.007 & 0.009 & -0.031 & 0.019 \\
\hline Soil pH $(\mathrm{pH})$ & - & - & 4.845 & 0.128 & - & - & - & - & - & - & -0.053 & 0.441 \\
\hline $\begin{array}{l}\text { Light indicator value } \\
\text { (L) }\end{array}$ & -3.886 & 0.006 & -4.074 & 0.003 & -0.167 & 0.134 & -0.241 & 0.046 & - & - & - & - \\
\hline $\begin{array}{l}\text { Nitrogen indicator } \\
\text { value }(\mathrm{N})\end{array}$ & -4.448 & 0.000 & -4.808 & 0.000 & -0.435 & 0.000 & -0.544 & 0.000 & -0.095 & 0.000 & -0.145 & 0.000 \\
\hline $\mathrm{C} \times \mathrm{pH}$ & - & - & -0.141 & 0.039 & - & - & - & - & - & - & 0.003 & 0.075 \\
\hline $\mathrm{C} \times \mathrm{L}$ & - & - & - & - & - & - & - & - & - & - & - & - \\
\hline $\mathrm{C} \times \mathrm{N}$ & - & - & - & - & 0.004 & 0.008 & 0.005 & 0.005 & 0.001 & 0.004 & 0.002 & 0.000 \\
\hline Random structure & gls & & g & & Random & ntercept & Random & tercept & Random & ntercept & Randon & tercept \\
\hline
\end{tabular}

